\title{
Influence of Sports and Games on Enhancing Students 'Academic Performance in Public Secondary Schools in Nyamagana District
}

\author{
Milambo Milambo and Titus O. Pacho
}

Department of Educational Foundation, St. Augustine University of Tanzania, Mwanza, Tanzania

Received: 11 Nov 2020; Received in revised form: 23 Dec 2020; Accepted: 11 Jan 2021; Available online: 20 Jan 2021 (C)2021 The Author(s). Published by The Shillonga Publication. This is an open access article under the CC BY license (https://creativecommons.org/licenses/by/4.0/).

\begin{abstract}
This study aimed at investigating the influence of sports and games in enhancing students' academic performance in public secondary schools in Nyamagana district. The study employed mixed research approach and convergent research design. The participants involved in this study were 87 students, 8 sports and games teachers and 4 head of schools making the total of 99 respondents. Also, data were collected through questionnaires and interviews. Moreover, the quantitative data were analyzed using statistical packages for social sciences (SPSS) while qualitative data were analyzed through thematic data analysis. The findings of this study revealed that students' participation in sports and games bring positive impacts on their academic performance. Sports and games promote cooperation and good relationship between students, teachers and other academicians. Also it was revealed that different challenges which face public schools in implementing sports and games were, lack of expert teachers in sports, lack of funds, poor government support, lack of sports and games facilities, lack of enough play grounds, and students' misbehavior. Also, the findings identified different strategies schools should do to enhance sports and games successful such, giving rewards, sports competition, well planning of sports and games programs and lastly but not the least is dedicating enough time for sports. The study recommended that, in order to implement sports and games in public secondary schools, government should promote good policies which favor sports and games in secondary schools, and establishing sports and games academy for children, may help others to grow up with their carrier.
\end{abstract}

Keywords- sports and games, Academic performance, public secondary school.

\section{INTRODUCTION AND BACKGROUND TO THE STUDY}

Research on the influence of sports and games in enhancing students' academic performance has been done in many areas around the world but not yet in Nyamagana District. That sports and games influence students' academic performance, students must be involved in sports and games so that they may become physically and mentally fit to handle all curricular and extracurricular activities such as English society, music, school government, arts, dancing, etc., which increase their academic performance. "It should be known that sports and games came to be Universal features of human culture, both past and present. Archaeological investigations have uncovered numerous artifacts from game playing sites around the world. These include implements related to games of physical skills, such as balls, and hoops, game boards, board games pieces and playing cards for games of strategy, and dice, used in games of chance" (Chick, 2015).

It is known worldwide that, sport and games activities are beneficial to the development of a child in school because it helps them to become physically and mentally fit, reduces their participation in bad behaviors because if they positively integrate into various activities such as religious activities, they will be disciplined and it also helps them to improve their talents. In different parts of the world students' academic performance become a critical agenda with relationship to 
sport and games activities. According to Mello and Worrell (2008) define the term extracurricular activities as organized groups or activities such as dance, football, and students government and may occur in or outside of school. From this notion, it is clear that extracurricular activities take place after formal class, especially in the afternoon and evening hours. These activities may include school clubs, sport and games, school debate, drama, fashion as well as religious program. Extracurricular activities are not formal curricular school activities and there are no marks or credit given to students who participate but rather they are get motivation in terms of material and word. Extracurricular activities play an important role in developing students' academic performance.

In America researches have been conducted on the importance of sports and games on academic performance of students and teen sport as well. It is the first report to offer in depth analysis into how different types of sports and games teens play impact to their health and well-being in order to identify opportunities to improve access to high quality sports programming for students in schools, (Hock, 2018).

The report shows that participation in sports and games has positive impacts on academic achievement to students, since it prevents, stress, overloaded academic in head, psychological problems and creates physical fitness or health at large. "It digs deeper by looking at the little-studied questions of whether adolescent health and educational success vary from sport to sport. Finally, the report identifies unique benefits and opportunities for improvement that exist within each sport to maximize the health benefits for teens. Sports participation has many benefits and positive attitudes toward educational work; because they stimulate academic performance resulting to higher grades for students" (Hock, 2018).

Also in United States of America (USA) students' participation in sports and games or other extracurricular activities started $19^{\text {th }} \mathrm{C}$ and those sports and games become a part of normal academic scheduleas curricular activities. They introduced literary clubs organized by students, dancing clubs, English clubs, science and arts clubs, journalism as well as newspaper (Massoni, 2011). Sports and games meant to help students to reduce bad conduct or bad behaviors such as robbery, alcoholism, early sexual engagement and dropping out from school. Through involvement in sports and games students get energy, health, develop unity and cooperation and develop new ideas and skills specifically in social aspect, (Hock, 2018).
Also student's participation in extracurricular activities started $19^{\text {th }} \mathrm{C}$ and these activities become a part of normal academic schedule. In different school at that time they introduced literary clubs organized by students, journalism as well as newspaper and found that extracurricular activities help students to reduce behavioral problems such as alcoholism, early sexual engagement and dropping out of school. Through participation in these activities students develop new ideas and skills specifically in social aspect. Also started in Japanese school extracurricular activities become a tool of transforming students and become a part of educational activities especially sport. Japanese schools have seen extracurricular activities such as sports as necessary for democracy, equality and shaping students discipline in various schools (Mendelbaum, 2005).

In Tanzania, the government determined the need to establish sports and games in public schools immediately after independence by establishing the National sports council under the ministry of education in 1967 With the purpose of stimulate students' academic performance. Whereby sports and games improve health of students, create active and creative students and cover psychological problems, the government decided to introduce UMISETA for schools, football Association of Tanzania (Omari, 2002).

In order for the country to reach expected goals in sports development in Nyamagana public secondary schools, the government should have a clear national sports policy, good sports administration as well as sports organization, plans, and sports programmers' in schools. These aspects help to improve sports development in schools (Omari, 2002). Therefore, this study aimed at examining the influence of sports and games on enhancing students' academic performance.

\section{Statement of the Problem}

The study about the influence of sports and games on enhancing students' academic performance using the theory of sports, intended to find out the influence of sports and games on enhancing students' academic performance. Scholars like Mandelbaum (2005) and Ivaniushina \& Zapletina (2015) identified that "sports and games are important part in everyday life of children and adolescents and affect various aspect of their life from academic achievement to manifestations of deviant behavior". Sports and games provide energy and healthy to students as well as a sense of unity, cooperation and discipline, which promote their academic performance. The absence of sports and games may 
lead to poor students' academic performance. Sports and games have been left behind in public secondary school compared to the earlier situation up to 1990 s, was the time which high concentration on sports and games in secondary schools ended. If sports and games are not considered in secondary schools, it may lead to laziness, poor relationship between students and teachers, diseases and disunity to students. The absence of sports and games in public schools may cause different problems to students in all aspects, social, economic and political and particularly in academic performance (Gorton, 2010).

Surprisingly, there are few researchers who have investigated the influence of sports and games in enhancing students' academic performance in public secondary schools. Even if there are empirical evidence indicates that participation in sports and games influence students' academic performance. Less consideration on sports and games in public secondary schools, led to poor environment for students to study and perform well. When students get enough time for sports and games provide students with funny, refreshment and improving energy of students which promote unity and cooperation, confidence and good relationships among students and teachers. Therefore, this study investigated the influence of sports and games on enhancing students' academic performance in public secondary schools in Nyamagana District.

\section{Specific Objectives of the Study}

i. To examine the impact of sports and games in enhancing students' academic performance in public secondary schools.

ii. To explore challenges schools face in implementing sports and games in public secondary schools.

iii. To examine strategies school should adopt to influence sports and games in public secondary schools towards students' academic performance.

\section{Significance of the Study}

The findings of this study are expected to increase knowledge and understanding to education managers, researchers, policy makers and other stakeholders such as teachers, students, government and parents, politicians on how students' participation in sports and games help them on achieving their academic performance. Not only that, but the findings may also be used by the stakeholders in creating good strategies on how to influence sports and games in public secondary schools, like preparing enough play grounds, jersey, sports and games competition both inside and outside the school, dedicating enough time for sports and games, since they contributes to academic performance of students by creating good relationships, confidence, unity and cooperation between students towards education activities such as group discussions and group presentations as well.

\section{LITERATURE REVIEW}

\section{Mandelbaum's Theory of Sports}

A theory in research is important since it is used as a guide on how the data can be collected and a mindset through which the researcher makes sense of the findings. Therefore this research was guided by a theory of sports coined by Michael Mandelbaum in 2005. This theory of sports stated that sports and games brings a diversion from the routines of modern life which is the most positive effect of sports, that sports and games promote a conducive environment for mental and physical fitness making participants, especially students feel better to handle other different activities, particularly in academic affair to bring success as well as achievements. This means that, they can perform other activities which help them to build their talents and they can enjoy being in schools. To believe only in the formal-curriculum may destroy other student's talents and discipline especially for those who are not well gifted academically (Mendelbaum, 2005).

\section{Students Involvement Theory}

Students' involvement theory was introduced by Alexander Astin in 1984 and put more emphases on involving students in different activities in college such as extracurricular activities such as sports and games which allow interaction with other people in college and campus. Astin (1999) students' involvement refers to physical and psychological energy that student devotes to academic experience. Thus the highly students is one, for example, devotes considerable energy to studying, spends much time on campus, participates actively in students organizations, and interacts frequently with faculty members and others members.

From this theory, it is believed that, students who get involved in different activities in school will achieve the best in their study and their personnel development. According to Smart (2003), based on what students become or develop into, and their personnel development depend on the amount of physical and psychological they invest in different programs. From this theory, there are a lot of benefits such as academic achievement derived from involving students in extracurricular activities. When students are positively involved and invest their energy in various school activities, it helps them to perform well in their study and other school program such as extracurricular activities. As such, it is clear 
that student's benefits more when they are directly involved in school program such as extracurricular activities. It is believed that extracurricular activities allow interaction between students, teachers and other member in the community (Manning, Kinzie and Schuh 2006)

In addition to that, schools should measure students' participation, for example by counting activities performed by students and time spent on it. Astin (2009) as cited in Paulsen (2013) stated that involvement may be measured quantitatively or qualitatively by direct observation or via self-report. This means that school extracurricular activities should be measured and grade should be emphasized so as to increase morality and creativity to perform as well as to improve student talent, abilities and capability during performance of these activities

\section{Concept of extracurricular activities}

Extracurricular activities as one dimension of curriculum practiced in different Tanzanian secondary schools. According to Adeyemo (2010) extracurricular activities are activities performed by students that fall outside the realm of the normal curriculum of schools. These activities are good in enriching students 'skills, discipline, physical fitness, talents as well as students who participated in extracurricular activities become creative. Acar and Gündüz (2017) identified kinds of extracurricular activities such as sports, music, painting, theatre, and literature which are out of class room contexts and performed in school. Jamal (2012) stated that, "extracurricular activities go beyond the classroom" activities and must fulfill two basic conditions: 1) they are not part of regular school curricular program and 2) they are structured towards a pro-social interactive environment. It is clear that, student's participation in these activities allow them to socialize and build peer integration which helps them to be good members of the school and the society in general

According to Hill et al as cited in Lunenburg (2010) identified some functions of extracurricular activities on students namely; reinforcing learning, supplementing course work, integrating knowledge and democratization. Through participating in extracurricular activities, students are able to learn new skills, allow students to integrate with other and it provide leisure time. This view is supported by Ahmad, Rahman, Ali, Rahman and Al -Azad (2015) argued that participation in extracurricular activities for students benefit them by attending class more regularly and having higher selfconcept. According to Lunenburg (2010) extracurricular activities have become part of values and virtues not only to American education but also to the democratic life. It is true that extracurricular activities contribute much on student's development in the aspect of talents and discipline due to participation in different activities done in school.

This section has contained the analysis and synthesis of literature related to the specific objectives. Therefore, this section has reviewed various related literature contextualizing assessment of the influence of sports and games on academic performance of students in public secondary school.

\section{Impacts of Sports and Games Participation to Student academic Performance}

According to Hock (2018) unique opportunities for improvement exist within each sport to maximize the health benefits for teens. Sports participation has more benefits and positive impacts towards educational work as it stimulates academic performance resulting to higher grades for students. Since sports and games create a conducive environment for students in secondary schools to learn better and achieve their expected goals in life time. Sports and games participation have positive impact on students' academic achievement or success since it builds confidence, discipline, unity and cooperation which brings bothintra-personal and interpersonal skills to students which help him or her to interact with other through group discussion and different seminars and workshops, simply to socialize with others in the process of learning or acquiring skills, experience and knowledge from each other. Also sports and games prevent students from diseases, psychological problems by offering energy, confidence, refreshment and joy and also create physical fitness to students who get involved on sports and games. According to Hill et al., (2004) as cited in Lunenburg (2010) identified some influence of sports and games on students including; reinforcing learning, supplementing course work, integrating knowledge and democratization. Through participating in sports and games, students are able to cooperate each other and learn new skills, allow students to integrate with other and it provide leisure time. This view is identified by Ahmad et al., (2015) argued that participation on sports and games for students provide positive impacts as well as benefit to them by attending class more regularly and having higher self-confidence and self-concept.

\section{Effective skills enhancement}

According to Ivaniushina and Zapletina (2015) on their study on participation in sports and games as well as extracurricular activities and development of personal and interpersonal skills in adolescents revealed that students who participated in sports and games activities offer a wide variety for developing various aspects of personality. For example, social skills, 
interpersonal skills, goal setting skills, self-identity and competencies especially for those who perform martial arts and sports. Students who involved in sports and martial arts have better skills at planning, time management, and setting priorities. Sports and games reinforce teamwork and they try themselves in different areas. Bhatia (2012) argued that students who engaged in extracurricular activities develop social skills, such as understanding different race and customs as he or she get interacted with different students from different customs. As well as individual skills such as self-confidence, and communication ability this activities develop students' verbal communication, ability to work in teams, mental alertness as well as self- confidence hence contribute to students' academic performance

\section{Provide creativity}

A study done by Olibie, Ifeoma and Ifeoma (2015) on curriculum enrichment for 21th Century skills, A case for art based extracurricular activities for students, revealed that student participation in extracurricular activities such as sports and games help to develop the 21st Century and such activities enhancing creativity thinking, productivity and wellbeing of students and help students to develop their personal and community development. For example students who engaged in drawings, playing and art based activity provide opportunities for students to be creative and innovative through making creative arts. Students who engage in dance serve a creative outlet for expression of selfenvironment. Dance helps to keeps body and brain active, improve strength and flexibility, posture and balance.

\section{Develop students' talents.}

According to Lazaro and Anney (2016) titled rethinking the role of co-curricular activities in developing students' talents in secondary schools in Tanzania revealed that students' who participate in co-curricular activities such as sports and games are more advantageous to develop talents. Another role observed in this study was co-curricular enrich students language skills and self-confidence.

\section{Develop discipline among students}

According to Muloiwa and Odimegwu (2018) identified that, participation in sports and games as well as extracurricular activities found to be beneficial to youth self-esteem and discipline. Extracurricular activities reduce risky behaviors such as sexual behaviors which associated with STI contraction including HIV/AIDS and illicit drug use associated with long- term addiction and liver disease which associated with illicit drug use with long term addiction. According to Massoni (2011), the study done in the positive effects of extracurricular activities on students' academic performance, in the United State of America, identified that sports and games as well as extracurricular activities help students to reduce behavioral problem, stress and isolation. Participation in these activities helps students to develop good behavior and to become well disciplined. Also participation in extracurricular activities for example, sports and games strongly positively associated students' development. Students who participated in these activities are less involved in engaged in risky behaviors such as smoking, drinking alcohol, robbery and Marijuana.

According to Massoni (2011) in his study argued that students who participated in extracurricular activities reduced behaviors problems. For example students who participated in sports they show discipline in drills, practice and routines. They have a responsibility of performing these activities correctly. In this study a students who participated in these activities are rewarded for good behavior and they take pride in their accomplishments hence they gain better self-respect, self-esteem and self-confidence.

\section{School leaders may face different challenges in influencing sports and games in public secondary schools}

School leaders may face different challenges in influencing sports and games in public secondary schools which in turn hinder the academic performance of students. Students may not participate in sports and games in schools due to lack of playgrounds and absence of sports materials like balls, nets, jersey, first aid kit, tables for tennis, cards for facilitating sports and games in schools (Rees \& Sabia, 2010).

\section{Financial problem}

This is a challenge towards enhancing sports and games in public secondary schools, whereby the school lack enough fund on establishing and support different sports and games, this is the results when most of public secondary schools do not have their own income generating projects or any means for fund raising to help them in establishing and maintaining sports infrastructures like playgrounds and lack enough fund to buy necessary sports and games materials or facilities like balls, jerseys, nets, cards and first aid kits. Instead, they depend on other external stakeholders such as the government and other academicians to provide such facilities, this situation limit the spread of sports and games and its' motivation to students, which may hinder the students' academic performance (Rees \& Sabia, 2010).

Also an investigation done by Haliimah (2010), on how sports and games programs in selected Inner-city secondary schools in South Africa identified that, financial resources to establish 
and implement sports and games are very limited compared to curricular financial resources. Because the shortage of school budget makes difficult environment to allocate a lot of money to establish and implement sports and games in public secondary schools. Since curricular programmers are given first priority. Funds allocated to establish and implement sports and games is not enough because investing as well as implementation of sports and games need or require an enough financial resources in facilitating, operating and administration.

In United States of America a study conducted by Moran (2017) identified that, there was financial problems due to in adequately fund allocated for extracurricular activities such as sports and games. This was a result of budgetary restraints and become challenges due to increase in costs of education and operational activities. This resulted to elimination of extracurricular activities such as sports and games in different parts of United States of America such as in Ohio schools.

\section{Lack of government support}

This also is a challenge towards enhancing sports and games in public secondary schools, when the government lack enough fund to support sports and games and has poor or wrong perception of sports and games, schools lack both moral and material support which hinders the developments of sports and games in public secondary schools. The government is the main change agent in influencing sports and games in public secondary schools by setting adequate budget for establishing and promoting sports and games, by building good playgrounds of football, netball, basketball, volleyball, hand ball and tennis, and buying necessary sports and games facilities like balls, jerseys, cards, boards, nets, and first aid kit. The government is also responsible for making policies on supporting sports and games so as to be considered as an important practice in public secondary schools in enhance students' academic performance (Rees \& Sabia, 2010).

\section{Lack of enough sports teachers}

In enhancing sports and games, schools need qualified or skilled sports and games teachers who have the ability on transmitting sports and games skills and knowledge to young students by teaching them, mobilizing, organizing and planning on influencing sports and games in public secondary schools. Most schools lack qualified or skilled sports and games teachers to ensure that sports such as football, basketball, rugby, handball, netball, volleyball and tennis are established and promoted in public secondary schools as lifelong practices for students' achievements. Sports and games promote good academic performance of students whereby they bring energy to students as well as physical fitness, confidence, build cooperation and unity. Moreover, professional sports and games teachers have strong passion for sports and games making students to get involved in sports and games for their own development and personal gain, especially on academic achievements or as careers (Mhando, 2015).

According to Salamuddiri, Harun and Abdullah (2011) on teachers' competence in school extracurricular management in Malaysia identified that, there is lack of skills and interest among teachers as well as instructors who are responsible for extracurricular activities such as sports and games in schools due to lack of extracurricular management courses organized for teachers. In these schools they lack experienced teachers hence their involvement in extracurricular activities is unsatisfactory. In Malaysian schools most teachers consider extracurricular activities as an onerous task and are less interested and motivated to carry it out. Likewise the study done by Rai et al (2004) in Nepal schools identified that, teachers have no enough skills and training on extracurricular activities. In some areas teachers they did not given training on extracurricular activities such as sports and games since those who being training was more theoretical and time given for practical activities was not sufficient and also trainers did not conduct practical activities during the training, especially in Music, creative, dance as well s sports and games.

Also according to Yusof (2017), in Saudi Arabia on teachers' attitude toward the use of extracurricular activities in enhancing students' speaking skills revealed that, teachers lack skills and experience on planning different extracurricular activities such as sports and games. Most of the participants (98\%) have got work load that hinder them from preparing them for more EFL extracurricular activities this was resulted with EFL, teachers' workload hinders them from performing different activities

\section{Lack of Motivation}

According to Chatzisarantis (2006), the study found that students are not motivated by their schools like giving them rewards, no appreciation, poor support, no enough time for sports and games as well as sports and games programs, absence of sports competition in schools and absence of play grounds. Therefore, poor motivation in school environment affect the influence of sports and games hence result into poor students' academic performance. Moreover, Bamidele, Bamidele \& Obaseki (2016), on their study about influence of sports and games recommended that lack of sports and games facilities or materials like play grounds, jersey, balls, and 
cards, absence of sports and games teachers and absence of rewards for winners are among the issues tend to demotivate the students. Thus students to participate in sports and games need to be motivated in order to improve their academic performance. Lack of enough fund, poor government support affect sports and games in schools, hence lead to poor students' academic performance.

\section{Limited time}

According to Kamau, (2011) identified that, day school students spend less time in sports and games as well as extracurricular activities and also time allocated to extracurricular activities is not enough especially for mixed day schools students. For instance 2-3 hours per week allocated for extracurricular activities is not enough. In mixed school time is not enough because students they should have to cover reasonable distance to home and they have to do this before it is dark which time risky is especially for girls.

\section{Shortage facilities}

According to Ohiorenum, (2008) on extracurricular activities and teachers' attitude on the girl-child and psycho-emotional preparedness in Nigeria revealed that most school failed to organize different extracurricular activities such as sports and games due to insufficient facilities such as playgrounds provided within the school, play items like balls, jersey, nets, first aid kit and whistle which are sporting facilities needed for extracurricular activities. This study identified that, there are no climbers and swings were found in any of the study school location. For example, most schools in this study have facilities for football, but have none for the volleyball, pitch, and Badminton court. It is difficult to organize different sports and games activities when there are insufficient facilities for different sports especially for the child-girl.

According to Kisango, (2016) in his study on factors influencing students' participation in co-curricular activities in public secondary school in Lamu County identified that, there were no adequate physical facilities for co-curricular activities as well as sports and games including basic facilities deprived students a platform to explore and practice their activities. In this study teachers agreed that in adequate sporting materials and in adequate knowledge by students on the availability of some facilities led to underutilization hindering many students from being involved in co-curricular activities of sports and games.

Also in a study conducted by Mtengule, (2013) identified that, in most of schools in Morogoro municipality there were no enough sports and games infrastructure facilities for every type of sports and games as well. The dominant infrastructures were for football, netball and basketball. But there were no areas reserved for volleyball, handball, baseball, rugby, and basketball, table tennis, boxing, jumping and swimming. Worthier some schools did not have completely the play grounds for any type of sports and games and some schools' grounds were used for constructing more buildings so as to accommodate the increasing number of students enrolled.

\section{Strategies to influence students to participate in sports and games for academic success}

According to Omari (2002), Tanzanian government determined the need of establishing sports and games at schools immediately after independence by establishing the National sports council under the ministry of education 1967 , with the purpose of stimulating academic performance to students in different schools, since sports and games improve their health, create obedience, provide energy, creative thinking and cover psychological problem. As such the government decided to introduce UMITASHUMTA, UMISETA, CHANETA, and Football Association of Tanzania (FAT), for all schools to get involved in sports and games, for the purpose of motivating sports and games to students when the government realized that there are importance for students to get involved in sports and games in order to increase their academic performance by giving students discipline, confidence, energy, constructive thinking, unity and cooperation with other students and teachers through participating in sports and games (Omari, 2002).

\section{Establishment of Sports and Games Programs}

The government is the key argent in taking steps to establish sports and games programs in schools by establishing physical education programs and sports certificate courses indifferent institutions such as in Butimba Teachers Training colleges, shirika la Elimu Kibaha in Kibaha District and in the university of Dar-es-Salaam through the faculty of education, with the aim of influencing students to participate in sports and games for their development and of students and teachers together. For the country to achieve its expected goals in sports development in secondary schools, the government must have a clear national sports and games policy, good sports administrators, sports organization and plans and sports programmers at schools. These aspects will also help to improve sports development in secondary schools (Omari, 2002).

\section{Promotion of Rewards}

According to Mbwana (2015),this strategy can enhance sports and games towards students' academic performance, Rewards should be given to students who win competitions for the 
purpose of motivating, influencing or encouraging them and other students to increase their efforts on cooperating with their fellow students on sports and games participation as well as academic affairs, something that could make themfeelbetter and appreciated so that to improve their creativity by thinking constructively, promoting discipline, unity and cooperation to them, where by appreciation give a student confidence which can also leadtogood students' academic performance. Also he identified that the provision of rewarding and bonus for the better performed students and teachers in order to motivate and rise the deadly heart and motivating students and teachers spirit which will increase performance and rise of educational system in Tanzania and reach expected goals or achievement of students' academic performance as well as recognition of best school which performed well, together which their teachers should be implemented and recognize and appreciated.

\section{Training sports and games teachers}

A study conducted by Mhando (2015), identified that implementation of physical education and sports curriculum at teachers colleges which provides a good future for the graduates. This is interpreted that implementation of sports and games enhancing students' academic performance. In order to get good sports and games teachers that are able to influence sports and games to public secondary schools the appointed sports and games teachers should attend sports and games course in different institutions like the university of Dar es salaam in order to help a particular sports and games teacher to perform different sports and games rules and strategies that lead to good students' academic performance (Mafumiko, 2008).

\section{Promoting Motivation}

Mafumiko, (2008) conducted a study on strategies for improving students' academic performance in Tanzania. The study came up with the findings that provide students with good playgrounds, sports and games competitions, enough budgets for sports, enough time for sports and games, influencing sports and games in schools which enhance students' academic performance. Therefore, availability of sports and games facilities and sports and games teachers influence students' academic performance in public secondary schools. Likewise Medic et al.,(2007) argued that, the intention of determining the strategies that can foster students' academic performance. The two studies revealed that rewards have greater effect on influencing sports and games in enhancing students' academic performance. Schools should be aware of what motivates students for instance some students are motivated not by rewards but others factors like enough time for sports and games, while others are motivated by rewards. Therefore schools have to take into consideration the good facilities for sports and games to students. According to Mar et al., (2016), study about the factors that may impact or influence sports and games in schools came up with the conclusion that in order to create the influence of sports and games in enhancing students' academic performance, the consideration on sports and games should be taken, mentoring sports and games programs and enough time for sports and games. This implies that by paying attention on ensuring good sports and games facilities increase the development of sports and games for the good students' academic performance.

\section{Government should ensure enough equipment}

According Bamidele, Bamidele and Obasaki (2016) on the study on assessment of the lack of sports equipment as constraint to the teaching and learning of physical education in secondary schools in Kogi state, Nigeria identified that secondary school principals should supply sports and games equipment to the schools so that any time the government release their capital grants the money can be deducted at source as such would enhance the teaching of the physical education as a subject in secondary schools of Kogi state. Again sport council should be equipped with the standard sports and games equipment needed to each the subject at a reasonable price, such as balls, jersey, whistles, cards, pictures, notebook, colors, and nets.

\section{RESEARCH METHODOLOGIES}

The study used mixed research approach which includes both qualitative and quantitative research approaches, because it provides a wide chance to conduct a study and brings awareness. Creswell, Plano \& Clark (2011), (Creswell, 2007).defined mixed method as the one which the data collection and analysis are done by using both quantitative and qualitative method in a single study or series of studies. The purpose of using the mixed method is that it gave a wide range of research methods and techniques of sampling, data collection, and data analysis.

\section{Research Design}

This study employed convergent parallel research design. According to Creswell (2012), a convergent parallel research design entails that the researcher concurrently collects both quantitative and qualitative data in the same phase of the research process, weighs the methods equally, analyzes the two components independently, and interprets the results together.. The convergent parallel design was used in the study to provide a unique example of real people in real 
situation for other readers to understand ideas properly (Kumar, 2011). Data were collected simultaneously and analyzed separately. Then the results were merged to help the researcher to understand the problem in details. Qualitative data were gathered from 4 head of schools who provided important information concerning the research topic. On the same time, quantitative data were gathered from 95 participants who provided the information concerning the research topic

\section{Sampling Technique}

The study used two sampling techniques namely, purposive sampling and random sampling. According to Kothari (2004), a sampling technique is a process of getting information about the entire population by examining only a part of it. Purposive sampling is a sampling technique which is more appropriate when the population happens to be small and a known characteristic of it is to be studied intensively.

The study used purposive sampling to select the District education officer and four heads of schools from four selected public secondary schools because their number is small and they have relevant information on the influence of sports and games on students' academic performance in secondary schools. Purposive sampling is useful in getting rich information from the selected respondents (Saunders $e t a l$, 2007), Kothari (2008), Random sampling gave every student a chance to participate in the study and therefore, will reduce the degree of biasness in data collection.

\section{Sample Size}

The sample size for this study was calculated by using Yamane's formula; this formula used to calculate the sample size from a population of 9135 . Therefore, the sample size for this study included 87 students, 8 sports teachers and 4 heads of school making the total of 99 respondents. Kombo and Tromp (2006) argue that a sample size is the group in a research study from which information is obtained; therefore a sample size is a group of individuals selected from the population for the intention of acquiring required information about the study. According to Yamane (1967) as cited in Singh and Masuku (2014) this is a simplified formula to calculate the sample size. The formula assumes that a confidence level of $95 \%$ and a precision level (sampling error) of $10 \%(\mathrm{P}=10)$.

The sample size was calculated using Yamane's formula as follows:

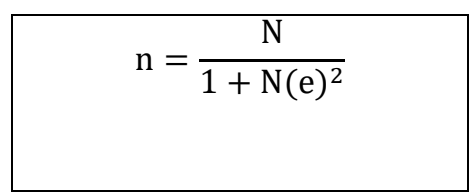

\section{Where;}

$\mathrm{n}=$ is the sample size

$\mathrm{N}=$ is the size of population

$\mathrm{e}=$ is the error of 10 percentage points

\section{Solution}

$\mathrm{n}=$ is the sample size

$\mathrm{N}=9135$

$\mathrm{E}=10 \%$

\section{Therefore}

Applying the formula:

$$
\begin{aligned}
\mathrm{n} & =\frac{\mathrm{N}}{1+\mathrm{N}(\mathrm{e})^{2}} \\
& =\frac{9135}{1+9135(10 \%)^{2}} \\
& =\frac{9135}{1+9135 \times(0.1)^{2}} \\
& =\frac{9135}{1+9135 \times 0.01} \\
& =\frac{9135}{1+91.35} \\
& =\frac{9135}{92} \\
\mathrm{n} & =99
\end{aligned}
$$

\section{Methods of Data Collection}

This study employed two methods of data collection, questionnaires and semi-structured interviews. The purpose of using these two methods is to get valid and reliable data since the use of a single method is inadequate in itself.

\section{Interviews}

According to Kothari (2004), (Hancock \& Algozine 2006). Krishnaswami (2003) semi-structured interview which means the use of pre-determined but flexible worded questions which give tentative answers to the researcher's questions. This study conducted face to face semi-structured interviews with four heads of school in four chosen public secondary schools in Nyamagana District. The interview used to collect in-depth information on school leadership roles, challenges and solutions in enhancing the provision of quality education. Further, the researcher made the interview guide available earlier so as to allow the respondents to be familiar with the 
questions and make preparations to respond freely during the interview.

\section{Questionnaires}

The questionnaires with both open and closed ended items used in this study to collect information from 08 sports and games teachers and 87 students. This was made purposively in order to enable the respondents to provide precise responses and to let them think critically and constructively when supplying their opinions and experiences that was important in understanding the research problem. The questionnaires were administered to respondents by the researcher as follows; the researcher gave some explanation to the respondents concern the purpose of the study and its significance.

\section{Pilot Study}

According to Creswell (2012), a pilot study is a procedure whereby the researcher tested his questions to some of his sample group so as to ensure the validity and reliability of the research tools. Reliability of the study done by exposing the questionnaires to my fellow colleagues who are teachers by profession Moreover, to ensure validity and reliability of the research instruments, a pilot study conducted prior to the date of study. Reliability is the stability and consistency of the measurement on the research instruments by making sure there are no error or bias from the respondents or the researcher. The data obtained were coded and analyzed by using Statistical data analyzing software SPSS version 20. The research instruments were found to be reliable and finally administered to the respondents during the actual study (Dawson, 2007).

\section{Validity and Reliability of the Instruments}

Validity is the extent to which the instrument measures what it purports to measure (Kimberlin and Wenterstein, 2008). The researcher in this study made sure the research instruments measure what was supposed to be measured. The instruments were exposed to colleagues and to the research supervisor; the researcher was advised to make modification of the instruments so that they could give the expected answers. The advice from the supervisor and fellow students helped the researcher to construct the questions which helped to collect data which were related to the topic under investigation and managed to have the answer of the problem due to valid questions constructed. Furthermore, reliability is the stability and consistence of the measurement on the research instruments by making sure there is no error or bias from the respondents or researcher (Dawson, 2007). In this study the questionnaires were exposed and administered to fellow teachers and filled. The data obtained were coded and used to calculate Cronbach's Alpha Correlation Coefficient of Reliability with the aid of SPSS version 20. The calculated Cronbach Alpha Correlation Coefficient of Reliability was $\alpha$ $=0.753$ signifying that the instruments were reliable. This form of reliability was employed because the questionnaires are administered once hence save time and cost. The research instruments were finally administered to the respondents that participated in the study.

\section{Data Recording and Analysis}

In this study, the quantitative data collected through questionnaire were analyzed using SPSS (Statistical Package for the Social Sciences) version 2.0. This study employed SPSS in calculating descriptive statistics and creating graphs and charts.

Qualitative data gathered through face to face interviews with the District education officers and heads of schools analyzed through content analysis; this is a type of data analysis where data gathered was categorized into themes and sub-themes, so as to be comparable. Moreover, content analysis gavethe researcher the ability to structure qualitative data collected in a way that satisfies the accomplishment of the research objectives (Moore \& McCabe, 2005). The qualitative data presented through elaborated descriptions and themes that convey multiple perspectives from the respondents, while the quantitative data presented using; tables, graphs and charts, this made the findings to be easily understood by readers.

\section{Ethical Considerations}

This study adhered to ethical issues that need to be addressed before, during collecting, analyzing, reporting, sharing and storing of data (Creswell, 2014). The researcher worked on obtaining the respondents' informed consent, observing their right to privacy, protecting them from harm which may be either physical or emotional by the way in which the researcher asked questions and reports the findings.. Ethical issues included voluntary participation, permission informed consent, confidentiality and avoiding harm to respondents involved in the study (Lekule, 2014). Ethical issue is the process of considering rules and regulations that assume to be correct in a given profession or group (Kumar, 2011). This implies that ethics observe the ability of individual to do right things according to one's needs or societal needs or organizational needs. Pacho (2015) identified that when one conducting social science research it is important to consider ethical issues. 


\section{Findings presentation and discussion}

This study intended to examine the influence of sports and games in enhancing students' academic performance in public secondary schools in Nyamagana District. This chapter presented the findings in relation to the objectives of the study.

\section{The Impact of Sports and Games in Enhancing Students' Academic Performance}

The first research objective intended to determine the impacts of sports and games in enhancing students' academic performance in public secondary school in Nyamagana District. The findings identified that students' participation in sports and games bring positive impacts on their academic performance. Sports and games promote cooperation and good relationship between students, teachers and other academicians. Sports and games foster students' physical fitness build their confidence; promote joyfulness and discipline which provide students with the ability to manage their academic activities well towards its success. The establishments of sports and games in schools have positive effects to students' performance in their examinations. The schools can use rewards and dedicate enough time for sports and games to motivate students to participate in sports and games resulting in improved academic performance.

Therefore, the absence of sports and games in public secondary schools destroy students' ability to perform well in their studies and examinations because of stress, disunity, lack of confidence, diseases and lack of cooperation in different academic activities. Due to this circumstances student found themselves performing poor in their studies automatically. The study also found that most schools do not have access to facilities of sports and games for students. The lacks of access to these facilities make students to miss important practices that improve their academic success. This condition disunites students and makes them to have negative perceptions towards sports and games and studies and large. For example, student's dropout of school due to the absence of sports and games, since sports and games attracts students' attendance in secondary schools. Moreover, students may lack the ability of think creatively due to absence of sports and games. According to (Hock, 2018), unique benefits and opportunities for improvement exist within each sport to maximize the health benefits for students. Sports participation has more benefits and positive impacts towards students' educational development because it stimulates students' academic performance and higher grades.

\section{Challenges Public Secondary Schools Face in Enhancing Sports and Games.}

This section has presented data on challenges schools face in enhancing sports and games in public secondary schools. The respondents were to answer to questions on challenges public secondary schools face in enhancing sports and games in Nyamagana District. The responses were as follows.

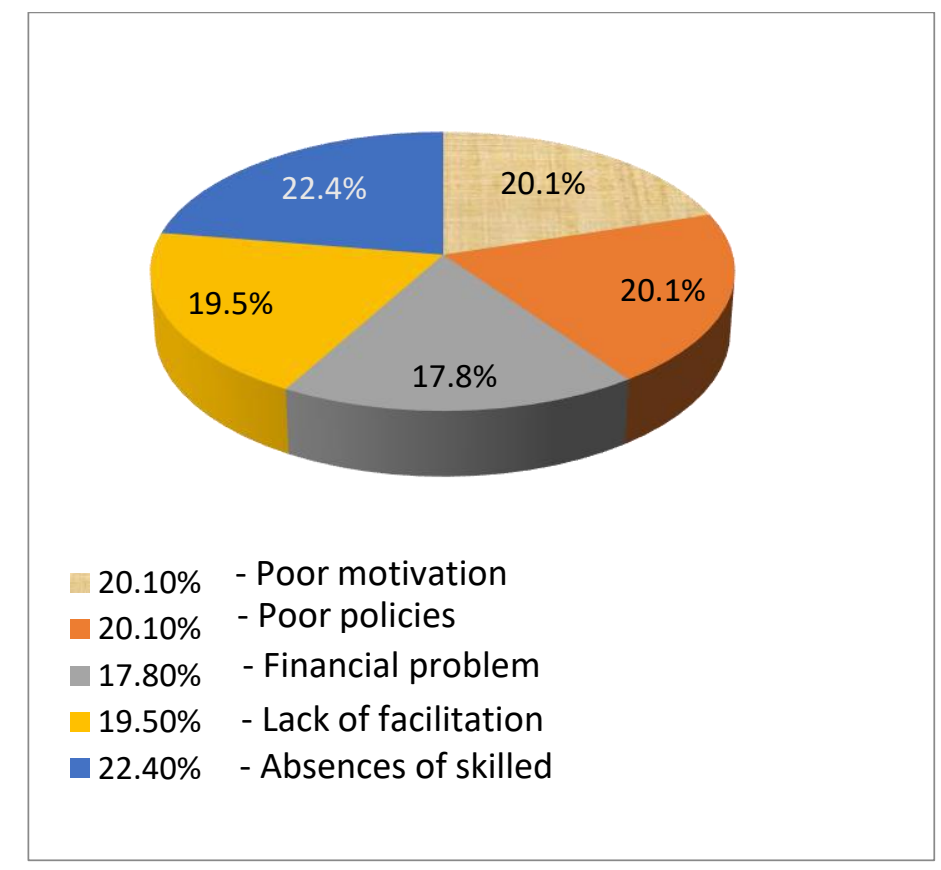

Fig.1: Challenges public secondary schools face in enhancing sports and games. 
The questionnaires provided to students and teachers identified that a majority of them strongly is agree that the absence of skilled teachers $(22 \%)$. The findings indicated that $(20 \%)$ students and teachers agree on poor motivation and poor policies together. Another challenge identified lack of

Table 1.: Challenges School face in enhancing the sports and games facilitation like playground and ball (20\%) and a minority $(18 \%)$ agreed there is financial problem in influencing sports and games in public secondary schools, led to poor academic performance of students.

\begin{tabular}{llcc}
\hline \multicolumn{1}{c}{ Challenges } & Frequency & Percentage \\
\cline { 2 - 4 } & Poor motivation & 70 & $20 \%$ \\
& Financial problem & 62 & $18 \%$ \\
& Lack of facilitation & 68 & $20 \%$ \\
& Poor policies & 70 & $20 \%$ \\
& Absence of skilled teachers & 78 & $22 \%$ \\
Total & 348 & $100 \%$ & \\
\hline
\end{tabular}

Source: Field Data (2019).

Table has indicated challenges facing public secondary schools in Nyamagana District in enhancing sports and games as pointed out by the respondents. They include; absence of skilled teachers, poor motivation, poor sports and games policies, financial problems, lack of facilitation facilities like playground, jerseys, cards and first aid kits.

\section{Challenges schools face in implementing sports and} games in public secondary schools.

The study findings established that in the selected public secondary schools in Nyamagana District, there were challenges they face in enhancing or implementing sports and games towards improving students' academic performance. These challenges were, lack of expert teachers in sports, lack of funds, poor government support, lack of sports and games facilities, lack of enough play grounds and students' misbehavior. In the study the respondents identified challenges public secondary schools face in implementing sports and games. since sports and games in one side influence students' academic performance, whereby sports provide a good environment for them to study well, hence reach their expected goals and achievements by giving them the spirit of unity and cooperation, confidence and sharing knowledge with others. On other side absence of sports and games may in the findings objective two on the challenges facing implementation of sport and games activities indicate that, there are numerous challenges facing implementation of these activities in schools, including lack of skilled personnel, limited time, insufficient funds, un conducive environment, low motivation and insufficient facilities were the challenges faced in the implementation of extracurricular activities. This result implies that, there are a lot of problems faced in implementation of extracurricular activities in schools. Most respondents agreed that in Nyamagana district, there are financial constraints to run these activities from school level to district level. The findings also indicated other challenge as lack of skilled personnel to implement different activities in school. Moreover limited time allocated for extracurricular activities by school were also challenges identified. The findings indicate that the schools did not have enough facilities which would help in easier implementation of sport and games, low motivation among teachers, students and administrators resulted to less participation in extracurricular activities by students. The findings also indicated other challenges as financial constraints to run extracurricular activities, The identified challenges were;

\section{Financial problem}

This is a challenge that hinders enhancing of sports and games in public secondary schools. The respondents indicated that most public secondary schools do not have income generating projects and fund raisings to them maintain old sports buildings and playgrounds and also buy necessary sports facilities like balls, jerseys, cards and first aid kits. Instead, they depend on other stakeholders such as the government and other academicians to mitigate this financial problem. According to Zvapano (2017) financial problem in enhancing sports and games is discussed where it was found that it is a challenge which hinders the development of sports and games in different institutions. Financial support is needed in enhancing sports and games with the purpose of running different activities concerned with sports and games, for 
instance, managing part-time coaches, preparing rewards, building playgrounds and buying necessary sports and games materials such as balls, jerseys, cards and first aid kits.

According to Moran (2017) in his study done in united states of America identified that there is financial problem due to budgetary restraints, due to increases cost of education and operational activities hence abolition of sports and games as we as physical education activities in some district in US such as Ohio District. The respondents indicated that there was disunity among students and teachers as well as head of schools in public secondary schools, whereby they have a negative perception on the information given by the heads of schools and this raises financial problems which hinder the provision of sports and games. That many schools don't have generating income projects which may help schools to facilitate sports and games by building playgrounds and buying sports and games materials such as balls, jersey, cards, nets, and first aid kid which support and promote the development of sports and games in public secondary schools. It was also identified that the absence of sports and games for students leading to poor academic performance.

\section{Lack of government support}

When the Government has spoor or wrong perception of sports and games, schools lack both moral and materials support which hinders the provision of sports and games. Based on the findings of the study, the government is the main change agent of influencing sports and games in public secondary schools by setting adequate budget for sports and games, especially for building playgrounds and buying necessary sports and games facilities such as balls, jerseys, cards, boards, nets and first aid kits. The respondents also suggested that the government should make policies to make sports and games to be considered as important activities in public secondary schools to enhance students' academic performance. According to Sanders, (2014) lack of government support was identified as one of the barriers which hinder the development of sports and games in secondary schools. Lack of support from the government for sports and games make them to disappear from schools.

\section{Lack of professional sports and games teachers}

In enhancing sports and games, public secondary schools need qualified or skilled sports and games teachers who have the ability to mobilize, organize and plan sports and games activities. The respondents suggested that most public secondary schools lack qualified or skilled sports' and games' teachers to ensure that sports such as football, basketball, rugby, handball, netball, volleyball and tennis are established and maintained as lifelong practices for students. Sports and games in schools promote good academic performance for students because of cooperation with each other and physical fitness from sports and games. Moreover, the respondents also noted that professional sports and games' teachers have strong passion for them and this ensures that sports and games are considered as important activities that students should get involved in for their own personal gains, especially for their academic successes. It is important to have professional sports' and games' teachers because teachers who lack enough experience, skills and knowledge on sports and games cannot manage sports and games properly in public secondary schools, teachers and students also work together in enhancing sports and games (Osborne, 2016).

\section{Poor Motivation}

From the study it was found that poor motivation is among the barrier which hinder the influence of sports and games in enhancing students' academic performance. Poor motivation was identified the source of poor students' academic performance. Motivation plays a great role in enhancing sports and games in public secondary schools. Students are not motivated by only giving them time for sports and games but also facilities like playground, balls, jersey, and cards are important in motivating students. Some of other motivation for students includes rewards, sports and games competition and good sports and games programs. The importance of recognizing students who win different competitions as one of the motivation make them to feel comfortable and appreciated, the similar concept was also discussed in (Kirk, 2010). Moreover motivating students participating on sports and games build conducive environment for students' academic performance on attaining their achievements. Poor motivation in sports and games leads to poor students' academic performance, because they will lack energy, unity, discipline, and cooperation.

\section{Strategies public secondary schools should implement to influence sports and games towards students' academic performance.}

This section has presented findings on possible strategies that public secondary schools could implement to influence sports and games towards students' academic performance in Nyamagana District the responses were as follows. 


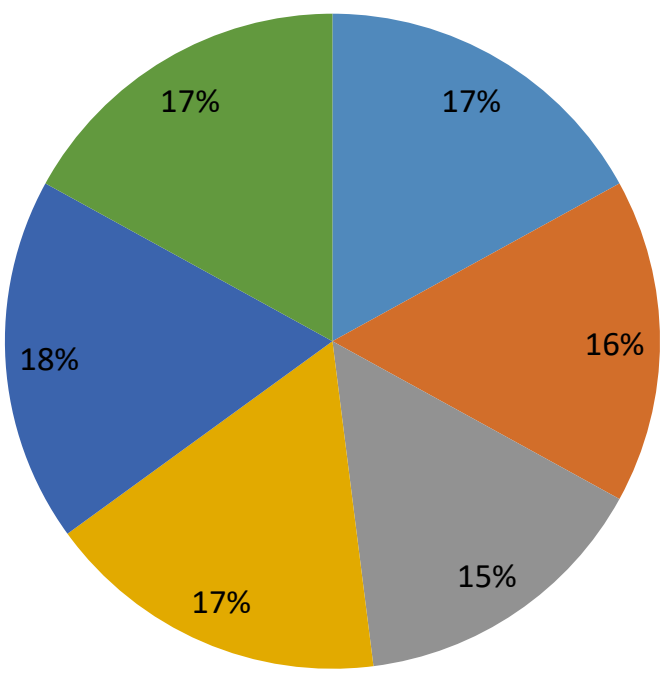

Motivation

Sports competition

Reward to students

Amount of time for sports

Sports and games programs

Enough play grounds

Fig.2: Strategies public secondary schools should implement to influence sports and games towards students' academic performance.

Table2. Possible strategies school should do to influence sports and games at schools towards students' academic performance.

\begin{tabular}{llc}
\hline Strategies & Frequency & Percentage \\
\hline Motivation & 77 & $17 \%$ \\
Sports competition & 70 & $16 \%$ \\
Rewards to students & 67 & $15 \%$ \\
Amount of time for sports & 78 & $17 \%$ \\
Sports and games programs & 80 & $18 \%$ \\
Enough play grounds & 78 & $17 \%$ \\
\hline Total & 450 & $100 \%$ \\
\hline
\end{tabular}

Source: Field Data (2019).

The table has shown strategies that public secondary schools should implement to influence sports and games towards improving students' academic performance in Nyamagana District. The findings revealed that, rewards to students, amount of time for sports, good sports' and games' polices, inter-school competition, are the strategies that public secondary schools should implement to influence sports and games towards improving students' academic performance. In the interview with the heads of school they were quoted saying that participating on sports and games influencing students' academic performance. Make students develop their carrier to meet their expected goals of achievements.

\section{Provision of Rewards}

When the heads of schools were asked on the strategies that can enhance sports and games towards improving students' academic performance, they suggested that, rewards should be given to students who win competitions, something that could make them to feel appreciated and improve their thinking ability and discipline. Therefore, they believed that, 
appreciation leads to good academic performance. In responding to this argument, first HOS said that:

Ilikuwe na hamasa za michezo Zaidi shuleni, wanafunzi wapewe medari (zawadi) pindi wanaposhinda michuano mbalimbali, kwa mfano wanafunzi wanao jituma Zaidi na kusababisha ushindi ndani ya timu zao,wapewe zawadi ili wanafunzi wengine wajitume na kuwapa motisha juu ya kujituma na kushirikiana na wanafunzi wenzao kila maeneo, Hivyo hii itawasaidia kuinua juhudi na kuinua uhamasishaji wa michezo miongoni mwa wanafunzi ambao pia huinua maendeleo ya taaruma na kufikia malengo yao kwa ujumla. [Translation: In order to influence sports and games in public secondary schools, rewards should be given to students who win the competition and those who put their effort on sports and games. This motivates other students to participate effective on sports and games, which create unity and cooperation among them on achieving their expected goals as well as good academic performance.]

\section{Trained Sports and Games teachers}

Teachers with sports and games skills are aware on training and guiding students and they have skills that are capable on enhancing sports and games in public secondary schools towards students' academic performance. Therefore it was suggested that, teachers should be trained or given skills on sports and games that ensuring the ability on establishing and promoting sports to students in public secondary schools, this also promote enough sports and games skills to teachers in establishment and implementing sports in public secondary schools, lead to good students' academic performance.

The second HOS said that:

Walimu wa michezo inabidi wawena mafunzo na ujuzi wa michezo. Pamoja na kutumia uzoefu ila ujuzi na kipaji cha michezo kwa walimu wa michezo mafunzo ni muhimu sana katika kuhakikisha uhamasishaji wa michezo katika shule za sekondari za serikali. Mwalimu wa michezo aliyepitia mafunzo ana fahamu namna ya kufundisha, kuhamasisha, kukuza na kuimarisha michezo kwa wanafunzi ili kukuza vipaji vya wanafunzi tokea chini. Hivyo ana fahamu ni njia gani ya uhamasishaji aitumie ili kuhasisha michezo kwa wanafunzi wake na ana namna nyingi ya kufundisha na kuhamasisha.

[Translation: Sports and Games teachers need to be equipped with sports and games skills. Even if most sports and games teachers are using experiences and talents in influencing sports and games but training teachers is important in influencing sports and games in public secondary schools. A well trained sports and games teacher has skills on influencing and developing sports and games to students on identifying and developing talents of students. So he/she knows ways to influence sports and games to his or her students, since has different methods in motivating and promoting sports and games to students.]

Also the third HOS added that:

Kufundisha michezo ni kipaji lakini pamoja na kuwa na kipaji cha kufundisha michezo ni vizuri kukiendeleza kwa kupitia kozi mbalimbali ili kuimarisha maarifa na ujuzi wa kufundisha wanafunzi michezo. Mwalimu aliye pitia mafunzo anajua jinsi ya kufundisha na kuhamasisha michezo kwa wanafunzi mashuleni. Hivyo ni vyema walimu wa michezo wapiti mafunzo ya michezo kujifunza sharia na kanuni za michezo mbalimbali. [Translation: Leading sports and games is brilliance but also talents that need to be developed through various sports and games courses to enable one to be competent. A trained sports and games teacher have the ability on influencing sports and games in public secondary schools, it is better for sports and games teachers having sports and games trainings to learn sports rules and strategies.]

\section{Sports and Games competitions}

Public secondary schools should establish and develop sports and games competitions both inside a school and outside a school to compete with others on sports and games, for the purpose of strengthening sports and games in public secondary schools by influencing students to participate on sports and games for increase their academic performance and meet their expected goals

The another HOS said that:

Kuandaa mashindano au michuano na ligi mbalimbali katika michezo tofauti tofauti ndani na nje ya shule za serikali ili kukuza na kuendeleza michezo mashuleni. Hii inaimarisha kujiamini kwa wanafunzi na kukuza umoja, mshikamano na 
mahusino mazuri kwa wanafunzi wa ndani na nje ya shule, na kuchochea fikra za ushindani na ushirikiano kwenye masomo ili kufikia malengo yao kwa ujumla. [Translation: Public secondary schools should prepare different sports and games competitions for the purpose of developing and strengthening sports and games in public secondary schools. Sports and games competitions promote confidence to students, unity and cooperation as well as good relationship between students in their sports and academic activities. Also it motivates and rise competitive ideas in their studies for achieving their expected goals in their academic context.]

\section{Enough play grounds}

Enough play grounds in public secondary schools provide good access for different sports and games, whereby promoting different varieties of choices for students to choose kind of sport he or she like. It can be football, netball, handball, baseball, basketball and volleyball or whatever he/she likes to play. The presence of different many play grounds in public secondary schools influencing sports and games on enhancing students' academic performance.

The second HOS said that,

Serikali pamoja na uongozi wa shule za sekondari za serikali wahakikishe ya kuwa kila shule inatakiwa kuwa na viwanja vya michezo mbalimbali vya kutosha. Hii itasaidia kuhamasisha na kukuzavipaji vya wanafunzi kwanzia chini kwenda juu, sababu hutoa nafasi ya kila mwanafunzi kuonesha kipaji chake katika mchezo husika anao upenda toka moyoni mwake. Hapa husaidia kuimarisha mahudhulio mazuri ya wanafunzi kupata nafasi ya kujifunza/kusoma inayopelekea wanafunzi kufauru vizuri katika masomo yao. [Translation: Both Government and school management should ensure enough play grounds in public secondary schools. Whereby enough playgrounds motivate and develop different talents of students from the bottom, when they get enough chance to show what they like on sports and games. Also influence students' attendance in public secondary schools which increase students' academic performance.

Strategies public secondary schools should adopt to influence sports and games for students' academic performance.

The third research objective intended to find out possible strategies that public secondary schools can adopt to influence sports and games for students' academic performance. From the findings, the study identified that giving rewards, sports competition, and well planning of sports and games programs were the strategies for enhancing sports and games towards students' academic performance in public secondary schools.

\section{Provision of Rewards}

Based on research findings, rewards should be given to students who win competitions, something that could make them to feel appreciated and improve their thinking ability and discipline. Therefore, participants in the interviews believed that, appreciation results to good academic performance. For instance trophies, medals and even money if given can motivate winners to keep up efforts in ensuring stiff competition in sports and games towards students' academic performance. Rewards motivates students towards physical education and sports participation, whereby students desire to put in more effort on sports and games to win competitions, thereby, promoting sports and games in secondary schools to enhance students' academic performance (Kirk, 2010).

\section{Sports competition}

Sports and games competition between classes (inter-class competition), and between schools (inter-school competition) allow students to get enough chance to participate in sports and games. From the research findings, the respondents suggested that sports competition reinforces unity, cooperation, confidence, provide energy/healthiness, mold discipline on students, and increase creativity in students. Collectively, they all these enhances students' academic performance. As such, schools should organize sports and games competitions since they motivate students to perform well academically (Moran, 2017).

\section{Dedicating enough time for sports and games}

Schools should set enough time for sports and games. The respondents suggested that dedicating enough time for sports and games for students help them to reduce stress, reduce academic overloaded and create fresh wonderful moments of joy. Together, all these enhance students' academic performance. The respondents also noted that giving students enough time for sports and games gives them the ability to think creatively and fosters creativity (Osborne, 2016).

\section{Motivation}

Respondents suggested that motivation to students is a way of influencing sports and games hence contributes to students' academic performance. Students need to be provided with different kinds of motivations in order to encourage them to participate in sports and games to the students' academic 
performance. For examples, motivations for the students include enough time for sports and games, sports and games competition and rewards. This makes students feel good, energy and unity to students, then good academic performance (Adeyeye \& Kehinde, 2013). Schools should make their efforts in providing motivation to students. The motivation can be in the forms of materials and non-materials. Non-material incentives may also satisfy students and raise their academic performance, for instance, when students are appreciated in sports and games which influence students' academic performance. In this study, the respondents indicated that, motivation to students is a way of enhancing students' academic performance. When students motivated on sports and games will increase their academic performance. In his study Byrne (2014) suggested that schools are supposed to support and give opportunities students to sports and games. Therefore proper motivation of students on sports and games result into students' academic performance as students will be happy and feeling recognized and appreciated can result into students' academic performance.

\section{Trained Sports and Games teachers}

In this study, most of the respondents identified that, training sports and games teachers is among the strategy of influencing sports and games to students in public secondary schools. The findings of the study also identified that, sports and games teachers should be trained on sports and games as well as physical skills that are managing them to have skills towards sports and games in different institutions. When teachers especially sports and games teachers are trained on physical skills or sports and games help them to understand the rules and strategies of sports and games. But when teachers are lacking sports and games skills or physical education skills, cannot be capable of training or influence sports and games to students in public secondary school hence fails to enhance students' academic performance. in the study of Peracek (2018) identified that the importance of training sports and games teachers that contribute to students' academic achievements. This implied that, when sports and games teachers have been trained on the best methods of practicing physical education skills or sports and games in school hence students' academic performance.

\section{CONCLUSION}

The research findings have identified the important role played by sports and games in enhancing students' academic performance in public secondary schools in Nyamagana District, Mwanza. In order to promote good academic performance of students and high quality education in public secondary schools, a combination of interrelated factors or extracurricular activities including sports and games, environmental clubs, English club, science clubs and PCCB clubs should be taken into consideration. The involvement of students in different activities at school, especially in sports and games foster their academic achievements. When students get involved in sports and games, it leads to improved health, cooperation, discipline, improved thinking capacity and gives energy for learning making student's to be able to concentrate in learning. According to Hock (2018), unique benefits and opportunities for improvement exist within each sport to maximize the health benefits for teens. Sports participation has more benefits and positive impacts towards education because it stimulates good academic performance and higher grades to students. Currently the Speaker of the National Assembly of Tanzania, Job Yustino Ndugai in a meeting he suggested what should be done in order to improve and influencing sports and games in our country in general. Whereby he suggested that; establishment of sports and games academy by clubs, private companies and institutions, the government and other private sectors should invest much on sports and games, to advice the ministry of education that sports and games should be important part in our curriculum, supplying enough delicious food to players from Wards, Districts and religions and also ensuring good sports and games leadership as well as managements. Sports and games improve students' academic performance as the theory of sports identified the unique benefit of sports and games to the students, and the theory of sport proposed by Mandelbaum (2005), which support sports and games that if anyone gets involved in sports and games may build confidence, energy, unity and cooperation. The theory identified that America's century-long love affair with team sports and games shows how sports and games respond to deep human needs, and also it identifies ways in which baseball, football and basketball became big national institutions and how they reached their present situation or forms which is good.

All in all the research findings have identified extracurricular activities participated by students in public secondary schools and the contribution of extracurricular activities on students' academic development. In order to develop students' academic performance schools should make equal priority on all dimension of curriculum and extracurricular activities significantly improve provision of education and curriculum development in general. Students involvement in extracurricular activities such as sports and games, school debate, school clubs, agricultural program become a way of 
developing students' talents and those who positively socialize increase creativity, reduce behavioral problems because students become well disciplined, improved skills and they become physically fit, improving behavior, increase school completion and make successful adults and social aspects.

\section{Recommendations}

i. Government through minister of education and vocational training should establish different project, seminars and work-shops for teachers, heads of school and district educational officers in order to get skills on extracurricular activities. With proper skilled teachers it will be easily to implement extracurricular activities in school because they can be aware on how to organize and supervise extracurricular for the benefits of the whole society.

ii. Parents and community members should be involved in initial stage in policy formulation in order to make effectively implementation of extracurricular activities in order to improve students, holistic development.

iii. Membership of the community should be political mobilized through education and training on the importance of extracurricular activities which lay an important role on development of a child in general.

iv. The government should employ teachers and support staff with required qualification to implement extracurricular activities. It should also employ education planners to work in schools so as to get effectively planned extracurricular activities.

\section{REFERENCES}

[1] Acar, Z. \& Gündüz, N. (2017). Participation Motivation for Extracurricular Activities: Study on Primary School Students. Universal Journal of Educational Research. Vol 5(5) pp. 901 $-910$

[2] Adeyemo, S., A. (2010). The Relationship Between Students Participation In SchoolBased Extracurricular Activities And Their Achievement In Physics. International Journal of Science and Technology Education Research: Vol 1(6). Pp. 111-117

[3] Ahmad et al., (2015).Effect of Extracurricular Activity on Student's Academic Performance. JAFMC, 11(2), 41-46.

[4] Apple, M. (1979).Ideology and curriculum. London: Routledge Kegan Paul

[5] Astin, A.W (1999) Students involvement: A developmental theory for higher education .Journal of College student development VOL 40 NO 5
[6] Benavot, A. \&Karmens, D. (1989).The curriculum content of primary education in developing countries. New York:World Bank.

[7] Chick, G. (2015).Games and Sports; Retrieved on $14^{\text {th }}$ December, 2018, from http://www.hraf.yale.edu/ehc/terms

[8] Coombs, Philip (1985). The World Crisis in Education. New York: DEMAC.

[9] Cooper, K, H, \& Morrow, J, R. (2016).Implementing Policies to Enhance Physical Education and Physical Activity in Schools: America.Texas: The University of Texas.

[10] Creswell, J. W. (2007).An Introduction to Mixed Methods Research: New York: Sage Publication.

[11] Creswell, J. W. (2012). Educational Research: planning, conducting and evaluating quantitative and qualitative Research (4th Ed). Boston: Pearson education Inc.

[12] David, N.M. (2014). Determinants of poor academic performance of secondary school students. Acase study of Sumbawanga. Morogoro: Sokoine University of Agriculture.

[13] Dawson, C. (2007). A practical Guide to Research Methods: A User-Friendly Manual for Mastering Research Techniques and Projects ( $6^{\text {th }}$ ed.). UK: Begbroke.

[14] Egan, K. (1979). Educational development. New York: Oxford University Press.

[15] Gorton, M. J. (2010). Exploring the impacts of sports participation on academic achievement in Middle School. Brockport: State University of New York.

[16] Haliimah, N. (2010). An Investigation of the Management of Extracurricular ProgrammesInSelected Inner City Secondary Schools: South Africa. Retrieved March, 2019 from https://uir.unisa.ac.za/dissertation-nalyazi-htm

[17] Hancock, D, R \&Alogazzine, B. (2006).Doing a case study research: A practical guide for beginning researchers.New York:NY Teachers College Press.

[18] Holsinger, D. B. \& Vowel, R. N. (2000).Positioning secondary schools in education in developing countries. International institutional institute for educational planning . Retrieved from: http://www.unesco.org.iiep

[19] Hock, L, (2018).Strong Athletes, smart students: The impact of Teen's sports participation on Academics. Retrieved from http://www.womanssports foundation.org

[20] Institute of Curriculum Development.(1990). A Summary Report on Baseline Survey on Primary, Secondary and Teacher Education Curriculum Reform in Tanzania Mainland.Dares Salaam.(Unpublished Document).

[21] Ivaniushina, V. A \&Zapletina, O. (2015). Participation in Extracurricular Activities and Development of Personal and Interpersonal Skills in Adolescents.Journal of Siberian Federal University Humanities \& Social sciences ,10(8), 24082420.

[22] Kimberlin, C. L \&Winterstein, A. G. (2008). Validity and Reliability of instrument used in research. American Journal of Health-System Pharmacist, 65(1), 2276-2284. 
[23] Kimberlin, C. L \&Winterstein, A.G. (2008).Validity and reliability of instrument used in research.American Journal of Health-System Pharmacist, 65(1), 2276-2284.

[24] Kirk, D. (2010) Motivational Profile For Secondary School Physical education: London:Routledge.

[25] Kombo, D. K. \& Tromp, D. (2006). Proposal and Thesis Writing; An Introduction. Nairobi: New Age International Publication Ltd,

[26] Kothari, C. R. (2004) Research Methodology, Methods and Techniques, (2nd Ed). New Delhi: New Age International Publisher.

[27] Kothari, C.P. (2006)Research methodology New Delhi: Wiley Eastern limited

[28] Creswell, J. W. (2012). Educational Research: planning, conducting and evaluating quantitative and qualitative Research (4th Ed).Boston: Pearson education Inc.

[29] Laura, E, (2017) The Role of Sports in Children's Education: Melbourne: Diaconia University of applied Science.

[30] Lazaro , A \&Anney V. N (2016) Rethinking The Role Of Co Curricular Activivities In Developng Students' Talents In Secondary School In Tanzania . Journal of Emerging Trends in Educational Research and Policy Studies. Vol. 7(2): pp. 152-166

[31] Lekule, C. (2014). Investigating school experiences of vulnerable children in Singida, Tanzania: Challenges, strategies, and possible interventions (Doctoral dissertation).Retrieved from scholar.uwindsor.ca/cgi/viewcontent.cgi.

[32] Lunenburg, C, F. (2010) .Extracurricular Activities Schooling.Boston: Sam Houston State University.

[33] Mandelbaum, M. (2005).The meaning of sports, retrieved from: https://www. amazon.com

[34] Massoni, E. (2011) Positive Effects of Extracurricular Activities on Students.Queensland:ESSAI.

[35] McGinn, N. F. \& Borden, A. M. (1995).Framing questions, constructing answers: Linking research with education policy for developing countries. Cambridge: Harvard Institute for Educational Development.

[36] Medic, N, Starkes, J, L, Mack, D, E \& Wilson, P, M, (2007).The Effects of Athletic Scholarships on Motivation in sports: Ontario: McMaster University,.

[37] Moran, J, P.(2017). Impacts of extracurricular activity on teacher job satisfaction.Retreaved on $6^{\text {th }}$ may, 2019 from https://etd.ohiolink.edu.

[38] Okoro, Z, G et al., (2016).Factors Influencing the Motivation of Sports Coaches in the Organization and Management of Sports Competition: Owerri: Municipal Council of Imo state

[39] Omari, (2002).OntarioThe role of sports associations in developing youth sports. Dar-Es-Salaam: University of Dar es Salaam Press.

[40] Pacho, T.O. (2015). Exploring participants' experiences using case study. International Journal of Humanities and Social Science, 5(4), 44-53.
[41] Roberts, J. M. Arth, M, J. \& Bush, R. (1959).“Games in culture” American Anthropologist. 61(4):597-605. Retrieved on $14^{\text {th }} \quad$ December, 2018, from http://www.doi.org/10.1525/aa.1959.61.4.02a00050.

[42] Sanders, B, (2014).Opportunities and challenges facing NGOs using sports as a vehicle: Ohio: The Ohio State University.

[43] Shuttleworth, M, (2008). Case Study Research Design. Retrieved Jan 25, 2019 from Explorable.com: https://explorable.com/case-study-researchdesign

[44] Tanzania Institute of Education, (TIE, 2010).Curriculum for ordinary level secondary education. Dar-es-salaam: TIE.

[45] Thapa, A. (2011).Does Private School Competition Improve Public School Performance? The Case of Nepal:Columbia: Columbia University Press.

[46] Wet, N. D., Muloiwa, T., \&Odimegwu, C( 2018) extracurricular activities and youth risky behaviours in South Africa .International Journal of Adolescence and Youth. Vol. 23(4) pp431-440

[47] Zvapano, K, (2017). Challenges in the Management of Sport in Universities in Zimbabwe: Harare: Zimbabwe Open University. 